\title{
Comentário sobre o Artigo: A Ética da Prevenção
}

\author{
Maria Fátima Olivier Sudbrack
}

Universidade de Brasília

\section{Comments on the Article: The Ethics of Prevention}

O texto é elucidativo das idéias e ideais do Prof. Richard no que concerne aos pressupostos que desenvolveu e defendia fervorosamente para o avanço das políticas de prevenção do uso indevido de drogas.

Aponta para a dimensão ética da prevenção, numa proposta de que o trabalho com os jovens busque, antes de tudo, a formação cidadã para assumir responsabilidades com maturidade. Enfatiza a formação de valores e o enfrentamento da realidade, numa postura crítica aos modelos de prevenção embasados em ideologias repressoras sob argumentos de que estes “...mais servem para ocultar a própria realidade que pretendem enfrentar."

Considero que ainda são pertinentes e atuais todos os ensinamentos e inquietudes expressas pelo autor no presente artigo, uma vez que as ações de prevenção junto às escolas, concretamente, ainda não se consolidaram no plano de ações de uma política nacional. No entanto, podemos apontar avanços no plano da definição de diretrizes para a prevenção, apontadas pela SENAD no PNAD - Plano Nacional sobre Drogas que segue, exatamente, a perspectiva apontada por Bucher, ou seja, o modelo da educação para a saúde. Uma vez firmada esta política, o grande desafio é a sua implementação com a capacitação dos educadores. Neste sentido, podemos nos congratular com o colega Richard pelo fato de que este trabalho já se inicia e se de- senvolve justamente junto ao Instituto de Psicologia onde as sementes foram lançadas...

Por iniciativa da SENAD e do MEC construímos, juntamente com diversos professores pesquisadores do IP e com a colaboração de outros autores, uma metodologia original e específica para curso a distância em prevenção do uso de drogas para educadores de escolas públicas. Após estudo piloto em 2004, esta metodologia torna-se a referência na política brasileira, em novo projeto para educadores de escolas públicas de todo o Brasil, totalmente executado pela UnB, sob nossa responsabilidade técnica no contexto do PRODEQUI- Programa de Estudos e Atenção às Dependências Químicas/PCL/IP.

O tempo passou, novos fatos relacionados ao contexto das drogas nos trazem desafios ainda mais instigantes. As políticas de prevenção prosseguem merecendo todo nosso investimento em pesquisa e ações políticas para seu avanço.

\section{Richard,}

Obrigada pelo caminho aberto! Este texto é um marco do que ficou como referência sua para todos que se dedicam ao tema, em especial para mim que tive o privilégio de tua convivência e da convivência com toda a equipe do CORDATO. 